Andrzej Górny

Uniwersytet Śląki w Katowicach

Agata Zygmunt

Uniwersytet Ślaski w Katowicach
Kiedy myślimy Rodzina..., red. M. Duda, K. Kułek-Sładek, Kraków 2016, s. 197-216 (Praca Socjalna w Teorii i Działaniu, 2).

DOI: http://dx.doi.org/10.15633/9788374385091.15

\title{
Internet a rodzina. O wpływie sieci na jakość więzi rodzinnych
}

\author{
Internet and family. The influence of the Internet \\ on family bonds
}

Abstract: The article contains the reflection on the role and meaning of Internet in contemporary family bonds creation. The times we live are described as "Web 2.0 era" or "Facebook epoque", which indicates the presence of Internet in various fields of everyday life. Internet is not only the space where we can find a fun, but it is also used for education, work and establishing or sustaining social interactions. Contemporary families' condition diagnosis stresses many problems which their members have to face. The most serious of them are: 1) the increase of generation gap, that determine misunderstandings and conflicts between family members also 2) dynamic migration processes that extend the distance between family members, which can be discussed in both: spatial and emotional aspect. We'd like to consider a multidimensional influence of the Internet, treated as a social phenomenon, on family's relations. In our opinion many examples of destructive influence of Internet on families' condition can be indicated. For example: a visible tendency to treat a virtual reality as an alternative for family life; looking for authorities and significant others in Internet; neglecting home duties which is the effect of intensive activity in the Web. On the other hand we can find some positive aspects of using Internet by family members. First of all it makes contacts between family members who are far away from each other easier. Secondly, it can be treated as 
a space of a common activity of all family. Thirdly, in the Web we can also find reasonable solutions of family problems.
Keywords: Internet, family bonds, family relationships, computer mediated communication

\section{Współczesne przemiany życia rodzinnego - kryzys czy nowy etap?}

Współczesna rzeczywistość to czas dynamicznych przeobrażeń społecznych. Są one zjawiskiem naturalnym - zmiana jest wszak immanentną cechą społeczeństwa, jednakże wydaje się, że ich tempo jest obecnie wyjątkowo szybkie. Transformacje są uwarunkowane wieloma czynnikami (wśród nich bez wątpienia jedną z naczelnych pozycji zajmuje masowo upowszechniający się internet) i dotyczą wszystkich właściwie aspektów życia społecznego. Głębokie zmiany ujawniają się tak w obrębie makrostruktur, jak i w odniesieniu do najbardziej elementarnych układów życia społecznego. Modyfikacje rzeczywistości społecznej odbijają się bardzo wyraźnie na kształcie struktur rodzinnych i sposobach ich funkcjonowania. Zbigniew Tyszka, charakteryzując specyfikę relacji między rodziną a społeczeństwem, pisze:

Rodzina ma swe istotne odniesienia do zewnętrznych w stosunku do niej układów społecznych - ze społeczeństwem globalnym włącznie (jako «układem układów»), podlega zewnętrznym wpływom i sama na zewnętrzny świat społeczny wpływa, pozostając z nim w nieustannej interakcji, a także ulegając przemianom wraz z przemianami społeczeństwa globalnego i jego struktur ${ }^{1}$.

Wśród badaczy nie ma jednak zgody co do tego, jak opisywać, interpretować i oceniać zmiany zachodzące w obrębie życia rodzinnego. Cytowany wyżej Zbigniew Tyszka podkreśla, że współczesna rodzina znajduje się niejako „pod naporem” wielu czynników zewnętrznych, które wpływają na jej gwałtowne, wielorakie przemiany. Ich oddziaływanie jest jednak niejednoznaczne - niektóre mogą wywierać wpływ pozytywny, np. w zakresie poprawy warunków życia (postęp techniczny, osiągnięcia medycyny etc.), inne zaś powodują dezintegrację i dezorganizację, naruszając podstawowe normy rodzinne regulujące funkcjonowanie rodziny i jej członków wewnątrz i poza nią².

1 Z.Tyszka, System metodologiczny poznańskiej szkoły socjologicznych badań nad rodzina, Wyd. Uniwersytetu Adama Mickiewicza, Poznań 1997, s. 31.

2 Por. Z. Tyszka, Rodzina współczesna - jej geneza i kierunki przemian, [w:] Rodzina współczesna, red. M. Ziemska, Warszawa 1999, s. 2. 
W opracowaniach naukowych poświęconych problematyce współczesnej rodziny można znaleźć wiele głosów wskazujących na ujawniający się na coraz szerszą skalę kryzys rodziny, prowadzący wręcz do jej dezintegracji. Jako przykład warto przywołać ujęcie Davida Popenoe, który analizując specyfikę funkcjonowania rodziny w Stanach Zjednoczonych, już w latach 90. XX wieku zwracał uwagę na fakt, że współczesna kultura wytwarza swoiście antyrodzinny klimat. Efektem tego procesu jest stopniowa destrukcja fundamentów życia wspólnotowego. W konsekwencji sytuacja ta może doprowadzić do poważnego zachwiania porządku społecznego ${ }^{3}$. Ten typ interpretacji opiera się na funkcjonalistycznym paradygmacie analizy zjawisk społecznych. Na jego gruncie podkreśla się, że tradycyjnie pojmowana rodzina przestaje wypełniać funkcje, które były jej przypisywane przez wieki. W odniesieniu do realiów naszego kraju ten sposób oglądu sytuacji współczesnej rodziny prezentuje m.in. Roland Łukasiewicz, który pisze, że rodziny w Polsce, egzystujące $\mathrm{w}$ niesprzyjających warunkach gospodarczych, politycznych i społecznych, przeżywają poważny kryzys. Jest on zjawiskiem wielowymiarowym (znajduje swoje odzwierciedlenie w wymiarze psychologicznym, biologicznym, ekonomicznym i społecznym). Widocznym przejawem tego stanu rzeczy staje się pogorszenie wielowątkowo rozpatrywanej egzystencji tej podstawowej struktury społecznej ${ }^{4}$.

Sygnalizowane poglądy nie stanowią jednak jedynej możliwej interpretacji. Rozpatrując sytuację rodzin Leon Dyczewski podkreślał, że zmiany zachodzące w obrębie szerszych struktur społecznych bez wątpienia wywołują kryzys rodziny - powinien on jednak być swoiście pojmowany. Jego zdaniem jednak należy rozumieć to pojęcie nie jako proces prowadzący do rozpadu rodziny, lecz jako tak zwany kryzys rozwoju, w wyniku którego rodzina kształtuje nowe wzory życia ${ }^{5}$. Pomimo upływu kilkudziesięciu lat od sformułowania tej tezy wydaje się, że dobrze oddaje ona specyfikę zjawisk zachodzących współcześnie. Dowodem może być pojawianie się i upowszechnianie nowych typów związków małżeńskich i struktur rodzinnych. Jedne z nich stanowią alternatywę dla małżeństwa jako związku kobiety i mężczyzny, inne wyznaczają nowe standardy życia w rodzinie. Te nietradycyjne relacje intymne stanowią nowe wzorce socjalizacyjne we współczesnym społeczeństwie i dynamizują dal-

3 Por. D. Popenoe, American Family Decline, 1960-1990: A Review and Appraisal, [w:] „Journal of Marriage and Family” Vol. 55, 3 (1993), s. 527-542, za: http://www.roper center.uconn.edu/public-perspective/ppscan/36/36022.pdf. (26.05.2015).

4 Por. R. Łukasiewicz, Potrzeby współczesnej rodziny jako aspekt ekskluzji, za: http:// wbs.lcs.net.pl/pliki/Lukasiewicz5.pdf. (26.05.2015).

5 L. Dyczewski, Rodzina polska i kierunki jej przemian, Warszawa 1981, s. 20. 
sze transformacje ${ }^{6}$. Nie ma zatem wątpliwości, że zmiany społeczno-kulturowe wpływają na relacje interpersonalne, owocując rosnącą liczbą nowych typów związków - alternatywnych względem tradycyjnie pojmowanej rodziny. Są one jej funkcjonalnymi ekwiwalentami. Wydaje się, że dzisiaj na dalszy plan schodzą kwestie związane $z$ instytucjonalnym wymiarem funkcjonowania struktur rodzinnych, podczas gdy kluczowego znaczenia nabiera ich aspekt emocjonalno-wspólnotowy. Warto także zauważyć, że coraz większa powszechność alternatywnych relacji małżeńskich i rodzinnych oraz ich rosnąca społeczna akceptacja prowadzą do przeobrażeń szerszych struktur społecznych.

Podobnie współczesną sytuację rodzin interpretuje Irena Pospiszyl. Uwzględniając fakt przeobrażeń w zakresie sprawowania funkcji o charakterze materialno-opiekuńczym przypisanych rodzinie, podkreśla rosnącą rolę tej struktury społecznej w zakresie zaspokajania potrzeb emocjonalnych i psychicznych jednostek funkcjonujących w realiach późnonowoczesnych. Odnosząc się do tej swoistej zmiany akcentów w zakresie funkcjonowania rodziny, pisze ona: „w sytuacji, kiedy - wydawałoby się - społeczeństwo posiada wszelkie atrybuty, aby zapewnić jednostce pełny, niezależny rozwój, rodzina nie tylko nie chyli się ku upadkowi, ale stała się tarczą ochrony indywidualności jednostki, źródłem zdrowia psychicznego"'. Warto przy tym zastanowić się nad zakresem pojęciowym terminu „rodzina”. O ile dawniej obejmowało ono tradycyjnie, prawnie i religijnie legitymizowany związek kobiet i mężczyzny oraz ich dzieci, o tyle współcześnie wydaje się opisywać o wiele bardziej złożony katalog możliwych wariantów koegzystencji w obrębie najbardziej elementarnych grup społecznych (kohabitacje, związki LAT, DINKS, monoparentalność z wyboru etc.).

Analiza koncepcji i ujęć dotyczących kondycji współczesnych struktur rodzinnych prowadzi do wniosku o współwystępowaniu dwóch wyraźnych tendencji. Z jednej strony można obserwować obniżenie wagi instytucjonalnego charakteru tradycyjnie pojmowanych małżeństwa i rodziny, ujawniające się m.in. w indywidualizacji całokształtu postaw życiowych jednostek, które prowadzi do stawiania własnego, partykularnego interesu ponad dobrem wspólnoty rodzinnej. Z drugiej jednak strony zauważyć należy zmiany w zakresie więzi rodzinnych, które zaczynają opierać się przede wszystkim na relacjach psychiczno-emocjonalnych, a nie instytucjonalno-rzeczowych. Można więc postawić tezę, że zasadniczym zadaniem współczesnej rodziny jest zaspokoje-

6 Por. B. Jankowiak, Nieformalne zwiazki jedno- $i$ dwuptciowe jako alternatywne formy życia małżeńsko-rodzinnego. Analiza jakości i stabilności relacji, „Studia Edukacyjne” 26 (2013), s. 156.

I. Pospiszyl, Źródła trwałości rodziny we wspótczesnym społeczeństwie, „Problemy Rodziny" 2 (1998), s. 18. 
nie psychicznych potrzeb jednostkowych, wspomaganie indywidualnego rozwoju oraz uzdolnień poszczególnych osób wchodzących w jej skład. Pozostałe funkcje tradycyjnie przypisywane rodzinie są bowiem coraz częściej realizowane przez wyspecjalizowane instytucje.

Kwestia interpretacji i waloryzacji wspominanych powyżej zjawisk jest jednak bardzo złożona. Staje się ona przedmiotem ożywionych dyskusji (prowadzonych nie tylko na gruncie naukowym) i wydaje się dziś niemożliwa do jednoznacznego rozstrzygnięcia.

\section{Internet a relacje międzyludzkie}

Internet jest siłą napędzającą rozwój społeczny i zmieniającą codzienne życie wielu ludzi. Mimo że wynalezione wcześniej technologie, takie jak druk czy telegraf, zrewolucjonizowały świat, to jednak żadne inne medium nie wywołało zmiany tak dynamicznej, szybkiej i rozległej, jak to się stało za sprawą interne$\mathrm{tu}^{8}$. Ewolucję internetu komentują Barry Wellman i Bernie Hogan, pisząc, że o ile pierwsza epoka internetu była okresem eksploracji, nadziei i niepewności, o tyle obecnie, w drugiej epoce, możemy mówić o czasie rutyny, upowszechnienia i rozwoju sieci?.

O tym, jak popularnym i szeroko wykorzystywanym medium jest internet w naszym kraju, świadczą dane zgromadzone przez Główny Urząd Statystyczny $\mathrm{w}$ roku $2014^{10}$. Zgodnie z informacją GUS, odsetek gospodarstw domowych wyposażonych w komputer wyniósł w badanym okresie 77\%, natomiast dostęp do internetu posiadało łącznie 74\% gospodarstw domowych, przy czym $71 \%$ gospodarstw korzystało z łączy szerokopasmowych.

Już pobieżny przegląd danych statystycznych, pokazujących stopień wykorzystania możliwości, jakie stwarza internet, pozwala uzmysłowić sobie jego zasięg i siłę oddziaływania. Aktywność podejmowana w sieci obejmuje szereg działań, bez których trudno dziś wyobrazić sobie codzienne życie. Zauważa to m.in. Manuel Castells, pisząc, że internet został w praktyce społecznej przystosowany do wszystkich aspektów życia ${ }^{11}$. Jak twierdzi Anna Przybylska, w komunikowaniu via internet „miejsca nadawcy i odbiorcy są wymienne, co określa

8 J. A. Bargh, K. Y. A. McKenna, The Internet and Social Life, „Annual Review of Psychology" 55 (2004), s. 574.

9 B. Wellman, B. Hogan, Internet $w \dot{z} y c i u$ codziennym, przeł. M. Filiciak, „Kultura Popularna” 12 (2005) nr 2, s. 40.

10 Prezentowane dane pochodzą z informacji sygnalnej GUS: Społeczeństwo informacyjne w Polsce $w$ roku 2014, www.stat.gov.pl (29.05.2015).

11 M. Castells, Galaktyka Internetu, przeł. T. Hornowski, Poznań 2003, s. 137. 
się jako interaktywność" ${ }^{12}$. Jej efektem jest dyfuzja informacji i innowacji, w tym innowacji społecznych, jak również kształtowanie się relacji społecznych. Tym samym „Sieć włącza się w dotychczasowe struktury społeczne [...], propaguje nowe formy kultury, wpływa na życie codzienne zarówno w nowatorski, jak i konwencjonalny sposób"13.

Jedna $\mathrm{z}$ fundamentalnych kwestii związanych z rosnącym znaczeniem internetu koncentruje się wokół pytania, w jaki sposób korzystanie z tego medium wpływa na relacje społeczne. Opinie na ten temat są podzielone. Jedni uważają, że internet wpływa niekorzystnie na związki między ludźmi ${ }^{14}$. Przyczynia się bowiem do zmniejszenia częstotliwości nawiązywania interakcji bezpośrednich (face to face), zubaża kontakty międzyludzkie, izoluje od siebie członków rodziny i zwiększa dystans między rodzinami i światem zewnętrznym ${ }^{15}$. Jest to z jednej strony rezultat ułatwień komunikacyjnych, jakich dostarcza sieć - rozmaite sprawy mogą być o załatwiane na odległość, online, co wymaga niewielkiego wysiłku ze strony jednostek, zmniejsza się tym samym ich motywacja do nawiązywania kontaktów bezpośrednich. Z drugiej strony pojawia się argument, że dzięki wielu zróżnicowanym formom aktywności, jakie oferuje przestrzeń wirtualna, jest ona na tyle atrakcyjna, że wygrywa konkurencję z ograniczoną rozmaitymi kontekstami (czasu czy przestrzeni) rzeczywistością offline. Osoby „wciągnięte w sieć” często zatracają się w niej, zaniedbując przy tym relacje z bliskimi. Zdaniem sceptyków złudne jest przy tym ich przeświadczenie, że nowe znajomości zawiązane za pośrednictwem internetu zastąpią im te „prawdziwe”, istniejące w „realu”, bowiem w Internecie tak naprawdę jesteśmy samotni.

$\mathrm{Na}$ drugim biegunie znajdują się poglądy tych, którzy zdecydowanie zaprzeczają twierdzeniu, że internet niszczy związki międzyludzkie. Takie stanowisko prezentują m.in. Caroline Haythornthwaite i Barry Wellman, którzy przytaczają wyniki licznych badań wskazujących na to, że ludzie kontaktują się przez internet z rodziną i znajomymi, poświęcając na to sporą część czasu spę-

12 A. Przybylska, Korzystanie z mediów, [w:] Wspótczesne społeczeństwo polskie, red. A. Giza, M. Sikorska, Warszawa 2012, s. 347.

13 B. Wellman, B. Hogan, Internet..., dz. cyt., s. 40.

14 Stanowisko takie prezentuje m.in. Kraut, który na podstawie przeprowadzonych przez siebie badań sformułował wniosek, że intensywne korzystanie z (nowego dla użytkowników) internetu powoduje zmniejszenie zaangażowania $w$ relacje towarzyskie i rodzinne, stany depresyjne i osamotnienie. Z kolei Erding dostrzegł, że wśród niektórych (intensywnych) użytkowników internetu zmniejsza się liczba relacji międzyludzkich oraz następuje spadek zaangażowania w życie społeczne. Por. M. Castells, Galaktyka..., dz. cyt., s. 142-143.

${ }_{15}$ R. Hughes Jr., J. D. Hans, Understanding the Effects of the Internet on Family Life, [w:] Handbook of contemporary families, red. M. Coleman, L. Ganong, Thousand Oaks, C. A. 2004, s. 506. 
dzanego $\mathrm{w} \operatorname{sieci}^{16}$. Ich zdaniem istnieje dodatni związek między częstotliwością korzystania $\mathrm{z}$ internetu a intensywnością relacji społecznych ${ }^{17}$. Niektórzy badacze świata społecznego, m.in. Jan van Dijk ${ }^{18}$, są krytyczni wobec twierdzenia, że w sieci pozostajemy samotni. Twierdzą oni, że bycie samotnym oznacza, że nie ma się nikogo, do kogo można się zwrócić w potrzebie. Tymczasem w Internecie lub przez internet możemy uzyskać wsparcie zarówno ze strony znajomych, jak i nieznajomych.

Wydaje się, że tak rozbieżne opinie na temat roli, jaką odgrywa internet w kształtowaniu relacji między ludźmi, mogą być skutkiem różnych sposobów patrzenia na społeczną rzeczywistość. Ścierają się tu dwa podejścia - jedno, które zakłada tradycyjne postrzeganie zbiorowości oraz ról społecznych, oraz drugie, w którym obraz świata społecznego został dostosowany do „życia z mediami”, implikujego uznanie pluralizmu typów interakcji społecznych, jak również modyfikację spojrzenia na zbiorowości społeczne i na więzi, które w nich występują. Pisze o tym Kenneth J. Gergen, zwracając uwagę na to, że „Technologie XXI wieku zarówno zwiększają różnorodność związków z innymi ludźmi, jak i modyfikują ich starsze formy. Gdy związki zmieniają się z bezpośrednich w elektroniczne, zmianie często ulega ich charakter. Stosunki, które były ograniczone do konkretnych sytuacji - biur, sypialni czy salonów - zostają od nich odklejone" ${ }^{19}$.

Rozważania na temat oddziaływania internetu na więzi rodzinne powinny naszym zdaniem - uwzględniać refleksję krytyczną, kierującą uwagę w stronę zagrożeń, jakie powoduje korzystanie (nierzadko nazbyt częste) z sieci przez członków rodziny. Jednakże nie można pominąć także roli, jaką medium to odgrywa w procesie budowania i zacieśniania więzi rodzinnych. Zgodnie z tezą Wellmana i Hogana będziemy więc traktować sieci komputerowe jako te, które mogą wspierać sieci społeczne. Przyjmujemy, że internet nie musi rozdzielać ludzi, ale raczej może zbliżać ich do siebie. Albowiem w epoce internetu „Związki międzyludzkie nie rozgrywają się wyłącznie osobiście, wyłącznie w sieci czy wyłącznie przez telefon - są raczej złożoną mieszanką niespodziewanych spotkań twarzą w twarz, umówionych wizyt, spotkań, pogawędek przez telefon, wymia-

16 C. Haythornthwaite, B. Wellman, The Internet in Everyday Life: An Introduction, [w:] The Internet in Everyday Life, red. B. Wellman, C. Haythornthwaite, Oxford 2002, s. $25-26$.

17 Za M. Castells, Galaktyka..., dz. cyt., s. 141.

18 J. van Dijk, Społeczne aspekty nowych mediów, przeł. J. Konieczny, Warszawa 2010, s. 235 .

19 K. J. Gergen, Nasycone Ja. Dylematy tożsamości w życiu współczesnym, przeł. M. Marody, Warszawa 2009, s. 97. 
ny e-maili z jedną lub kilkoma osobami i szerszych dyskusji sieciowych z osobami o podobnych zainteresowaniach"20.

\section{Internet a powstawanie rodziny}

Analiza wpływu internetu na jakość więzi rodzinnych nie może nie uwzględniać roli, jaką medium to może odgrywać w procesie tworzenia rodziny. Mimo mocno akcentowanych wartości indywidualistycznych, które wyznaczają współczesne style życia, założenie rodziny wciąż dla większości ludzi pozostaje priorytetem, celem, do którego będą wytrwale dążyć. Nie zawsze jednak udaje się w najbliższym otoczeniu znaleźć osobę, z którą chciałoby się spędzić życie i stworzyć dom.

W sukurs tym, którzy poszukują partnerki czy partnera, przychodzą portale randkowe, które są czymś w rodzaju internetowych biur matrymonialnych, oferujących kojarzenie samotnych osób. Oferta portali randkowych jest bardzo bogata. Najpopularniejszy w Polsce jest portal Sympatia.onet.pl, który (według danych z listopada 2014 roku) odwiedza około 1,06 mln internautów. Na miejscu drugim sytuuje się Singlessalad.com, który odwiedziło w badanym okresie 0,79 mln internautów. Trzecim pod względem popularności serwisem jest Edarling.pl, z którego skorzystało 0,69 mln użytkowników sieci ${ }^{21}$. Inne znane serwisy randkowe to: Sympatiaplus.onet.pl, Bemydate.mobi, Przeznaczeni.pl, Mydwoje.pl, Flirtuj.pl, Elmaz.pl, Fellow.pl czy Dopasowani.p122.

Jak twierdzą Robert Hughes i Jason D. Hans, czasy, kiedy szukający miłości w sieci byli stygmatyzowani i wyśmiewani, odeszły w zapomnienie i obecnie zauważalny jest znaczący wzrost liczby osób umawiających się na randki za pośrednictwem internetu ${ }^{23}$. Poszukiwanie partnera czy partnerki online jest pod wieloma względami łatwiejsze i wygodniejsze niż w świecie realnym.

Wbrew temu, co sądzą osoby sceptycznie nastawione do nawiązywania intymnych, emocjonalnych więzi w sieci, jakość tych relacji może być nawet nie tyle nie gorsza, co znacznie lepsza, niż to ma miejsce w przypadku znajomości powstających w świecie realnym. Internet bowiem pomaga w nawiązywaniu bliskich więzi. Przekonuje o tym Patricia Wallace, która twierdzi, że „sie-

\footnotetext{
20 B. Wellman, B. Hogan, Internet..., dz. cyt., s. 41.

21 http://interaktywnie.com/badania-i-megapanel/oto-najpopularniejsze-serwisyrandkowe-w-europie-250222 (30.05.2015).

22 http://www.wirtualnemedia.pl/artykul/top-10-serwisow-randkowych-sympatiawyprzedzila-edarling-w-gore-sympatiaplus\# (30.05.2015).

23 R. Hughes, Jr., J. D. Hans, Understanding..., dz. cyt., s. 508.
} 
ciowe przyjaźnie mogą być zarówno częstsze, jak i głębsze, niż mogłyby przypuszczać osoby, które nie mają internetowych przyjaciół" ${ }^{24}$.

Podkreślając znaczenie zapośredniczonych przez internet interakcji, Patricia Wallace zwraca uwagę, że przyjaźnie i związki zawiązane w sieci opierają się na takich samych zasadach i podlegają podobnym przemianom jak związki „realne”. Tak samo jak w „prawdziwym” życiu, tak i w świecie wirtualnym przyjaźnie i związki przeżywają swoje wzloty i upadki, okresy fascynacji i zaangażowania obydwu stron, jak i czasy stagnacji, obojętności, frustracji.

Warto podkreślić, że gros użytkowników portali randkowych dąży do tego, by przenieść znajomość zawartą online do rzeczywistości pozawirtualnej i kontynuować ją poprzez interakcje o charakterze bezpośrednim. W ten sposób internet staje się wyłącznie wielozadaniową swatką ${ }^{25}$, pośrednikiem w zawiązywaniu relacji bardzo realnych, kontynuowanych w „prawdziwym” życiu. Niejednokrotnie znajomość zawarta w sieci przekształca się w oparty na silnym uczuciu związek, którego partnerzy podejmują decyzję o wejściu w związek małżeński.

Przygotowanie do życia rodzinnego obejmuje także okres oczekiwania na narodzenie się dziecka. To ważne wydarzenie życiowe coraz częściej jest przeżywane (zwłaszcza przez młode kobiety przygotowujące się do nowej roli) za pośrednictwem internetu. Sieć staje się przestrzenią wymiany doświadczeń i wzajemnego wspierania się w tworzeniu własnej macierzyńskiej narracji. Można wobec tego stwierdzić - za Katarzyną Barani - że portale poświęcona rodzicielstwu oraz związane $\mathrm{z}$ nimi fora internetowe można traktować jako swego rodzaju wirtualną piaskownicę, w której kobiety kształtują swoją tożsamość jako matki ${ }^{26}$. Autorka zauważa też, że kształtowanie wspólnot opartych na podobieństwie w czasowym przeżywaniu ważnego życiowego wydarzenia, za jakie uznane być może oczekiwanie na dziecko, jest fenomenem niespotykanym dotąd w relacjach społecznych ${ }^{27}$. Przynależność do wirtualnej wspólnoty młodych matek ma na celu z jednej strony zdobycie praktycznych informacji związanych z macierzyństwem, z drugiej - doświadczenie wsparcia ze strony osób, będących w podobnej sytuacji. Jako że okres ciąży jest czasem, w którym kobiety mogą czuć się wyobcowane, ważne jest dla nich, aby poprzez aktywny udział $\mathrm{w}$ dyskusjach $\mathrm{z}$ innymi matkami poszerzyć swój świat.

Internet oferuje wiele stron internetowych przeznaczonych dla przyszłych rodziców. Należą do nich m.in.: www.mamazone.pl, www.ciążowy.pl, www.su-

24 P. Wallace, Psychologia Internetu, przeł. T. Hornowski, Poznań 2003, s. 178.

25 Tamże, s.177.

26 K. Barani, Wirtualne wspólnoty kobiet na forach internetowych jako źródło wsparcia w przygotowaniu do macierzyństwa, [w:] Całe życie w Sieci, red. B. Szmigielska, Kraków 2008, s. 177.

27 Tamże, s. 180. 
permamy.pl, www.babyboom.pl, ebobas.pl. Jednym z najpopularniejszych portali tego typu jest serwis www.edziecko.pl. Stanowił on obszar badań Katarzyny Barani, która postawiła sobie za cel dokonanie wstępnej analizy specyfiki korzystania $\mathrm{z}$ forów internetowych dla kobiet w ciąży i wyłonienie typów użytkowniczek, jak również sprawdzenie, jaką rolę odgrywa dla kobiet forum internetowe na tle innych potencjalnych źródeł wsparcia ${ }^{28}$. Wyniki przeprowadzonych przez nią badań wskazują, że użytkowniczki tego forum dzielą się na dwie grupy. Do pierwszej zaklasyfikowano kobiety, których celem jest budowanie poczucia wspólnoty, nawiązywanie przyjaźni z innymi kobietami, w której kontekście poszerzają swoją wiedzę o różnych aspektach macierzyństwa. Z kolej grupa druga skupia kobiety, które trafiają na forum, aby znaleźć konkretne informacje, nie wykazując przy tym skłonności do nawiązywania bliższych relacji z innymi kobietami. Charakterystyczne dla nich jest wycofywanie się z interakcji po osiągnięciu instrumentalnego celu. Autorka badań podkreśla jednak bardzo wyraźnie, że fakt korzystania $\mathrm{z}$ forów nie wynika $\mathrm{z}$ braku wsparcia ze strony partnera/ męża: w zasadzie dla wszystkich badanych kobiet pozostaje on najważniejszym źródłem emocjonalnego wsparcia. W formułowanych przez nią wnioskach znajduje się również stwierdzenie, że internet okazuje się dla przyszłych matek najważniejszym, obok lekarza, źródłem wsparcia emocjonalnego.

W kontekście przywołanych danych należałoby zastanowić się nad tym, dlaczego internet staje się dla młodych kobiet ważniejszym źródłem wiedzy na temat macierzyństwa aniżeli doświadczenia poprzednich pokoleń - chodzi przede wszystkim o wiedzę, jaka posiadają ich matki. Barani zwraca uwagę na fakt, że żyjemy obecnie w kofiguratywnym układzie kultury, który determinuje nabywanie aktualnie cenionej i przydatnej wiedzy, umiejętności i kompetencji od rówieśników, co uzasadniałoby frekwencję na forach internetowych dla młodych matek. Należy jednak z całą mocą podkreślić, że intensywność rówieśniczych kontaktów online podejmowanych przez kobiety w ciąży nie prowadzi do zaprzestania poszukiwania i doświadczania wsparcia ze źródeł „tradycyjnych”, takich jak rodzina, przyjaciele czy eksperci. Internet jest więc w tym zakresie raczej uzupełnieniem niż substytutem realnych więzi. Nie zastępuje ważnych dla kobiety osób, a raczej daje dodatkowe wsparcie, co w rezultacie lepiej przygotowuje ją do macierzyństwa.

\section{Internet a relacje małżeńskie}

Analizując opracowania dotyczące społecznych aspektów funkcjonowania rodziny, można odnaleźć różnorodne definicje rodziny. Pomimo rozbieżno-

28 Tamże, s. 182-199. 
ści większość z nich podkreśla specyfikę wzajemnych relacji zachodzących między jej członkami jako element konstytuujący tę zbiorowość społeczną. Przykładowo, według klasycznego ujęcia Jana Szczepańskiego rodzina to „grupa złożona z osób połączonych stosunkiem małżeństwa i stosunkiem rodzice - dzieci"29. Małżonkowie stanowią w niej zatem fundament, na którym opiera się cała mniej lub bardziej skomplikowana struktura rodzinna. Należy podkreślić, że na przestrzeni ostatnich dekad zmieniła się podstawa, na której opiera się ta bazowa dla funkcjonowania rodziny relacja. O ile dawniej duże znaczenie w podtrzymaniu trwałości małżeństwa miały czynniki o charakterze materialno-rzeczowym, o tyle dzisiaj akcent ten przesunięty zostaje na kwestie związane z możliwością zaspokajania potrzeb psychiczno-emocjonalnych.

Efektem tego przesunięcia, jak się wydaje, jest spadek trwałości związków małżeńskich. Dane gromadzone przez instytucje jednoznacznie wskazują na znaczące zmniejszenie stabilności tego podstawowego stosunku społecznego. Według danych Głównego Urzędu Statystycznego w 2013 roku liczba rozwodów w Polsce wyniosła ponad 66 tys., a wskaźnik rozwodów ${ }^{30}$ osiągnął blisko 37\%, podczas gdy w 1980 roku odnotowano jedynie nieco powyżej 39 tys. małżeństw rozwodzących się, a ich wskaźnik zbliżał się do $13 \%{ }^{31}$.

W naszej opinii jednym z czynników warunkujących tę sytuację może być powszechna dostępność internetu. Okazuje się bowiem, że wśród mnogości dostępnych dla każdego użytkownika stron WWW bez trudu odnaleźć można swoiste „poradniki” ułatwiające przeprowadzenie (nadal dość skomplikowanej) procedury rozwodu. Zasadnicza idea ich działania sprowadza się do hasła, które można odczytać na stronie głównej portalu Rozwód.pl: „Wszystko dla Twojego rozwodu. Szybko - pewnie - korzystnie" ${ }^{32}$. Oferują one dostęp do zróżnicowanych usług związanych z przeprowadzeniem rozwodu. Przede wszystkim stanowią bogate źródło wiedzy związanej z procedurą sądową. Otwierając kolejne zakładki, użytkownik może zapoznać się z aktualnym stanem prawnym i rozwiązaniami legislacyjnymi dotyczącymi rozwodów. Co jednak ważniejsze, za ich pośrednictwem można łatwo wynająć prawnika, który będzie reprezentował interesy zainteresowanej strony, a także możliwe jest oszacowanie kosztów całego postępowania. Ponadto w zakres oferowanych usług wchodzi wycena majątku (niezbędna przy regulowaniu kwestii finansowych). Użytkownicy mogą także zasięgnąć informacji o kwestiach podatkowych i możliwych do wykorzy-

29 J. Szczepański, Elementarne pojęcia socjologii, Warszawa 1972, s. 149.

Odsetek rozwodów w porównaniu do nowo zawiązanych małżeństw.

Za: Rocznik Demograficzny GUS, Warszawa 2013, s. 280-299.

Zob. http://www.rozwod.pl/ (27.05.2015). 
stania rozwiązaniach prawnych pozwalających na minimalizację ekonomicznych konsekwencji rozwodu.

Ponadto zauważyć należy, że takie internetowe poradniki mocno koncentrują się na psychologicznych aspektach rozstania. Za ich pośrednictwem można uzyskać wsparcie pozwalające na w miarę płynne wejście w nową sytuację życiową. Oferowane są bowiem za ich pośrednictwem konsultacje psychologiczne, a także prezentują one w syntetycznej wersji propozycje holistycznych strategii życiowych, które mogą być wykorzystane w nowej sytuacji społecznej.

Nie mniej istotne są kwestie dotyczące rozwiązań w zakresie opieki nad dziećmi - w tym przypadku również w sposób pełny i wielowymiarowy prezentowane są możliwe alternatywy dotyczące życia po rozwodzie, a zarazem omawia się możliwe sposoby walki o własne racje w tym zakresie.

W naszej opinii można postawić tezę, że powszechny dostęp do omawianych portali może przyczyniać się do rosnącej liczby rozwodów. Nie ma dziś wątpliwości, że internet jest pełnoprawną przestrzenią społeczną. Fakt przedstawiania w sieci rozwodu jako względnie przykrej, lecz także dość łatwej do przeprowadzenia procedury, po zamknięciu której można rozpocząć nowe życie, może się przyczyniać do podejmowania decyzji o rozwiązaniu małżeństwa. Dawniej konieczność przejścia przez postępowanie sądowe stanowiące wielka niewiadomą, mogła stanowić powód zniechęcający do podjęcia kroków zmierzających do rozstania. Jeszcze istotniejszym czynnikiem zniechęcającym do formalnego zakończenia związku był stygmat społeczny ciążący na rozwodnikach i rozwódkach. Dzisiaj portale internetowe ukazują rozwód jako przekroczenie kolejnej życiowej granicy, a życie po rozstaniu według tej wizji stanowi dalszy, naturalny i oczywisty etap egzystencji każdego człowieka.

Analizując kwestie związane $\mathrm{z}$ wpływem na relacje małżeńskie treści umieszczanych na stronach WWW, nie można jednakże pominąć aspektu terapeutyczno-wzmacniającego. Okazuje się bowiem, że osoby zmagające się z problemami dotyczącym współegzystencji z małżonkiem, prócz szeregu serwisów ułatwiających definitywne rozwiązanie problematycznego układu, mogą odnaleźć także portale, które ukierunkowane są na pomoc w zakresie kryzysów małżeńsko-rodzinnych. W opozycji do przywoływanego powyżej portalu, można wskazać stronę: www.rozwodpoczekaj.org.pl. Jak wskazują deklaracje jej twórców, podstawą stworzenia tej przestrzeni internetowej stało się przeświadczenie o wartości rodziny jako najlepszego systemu dla rozwoju człowieka. Podkreślają oni, że z jednakową troską traktują rodziny oparte na związkach formalnych, jak i nieformalnych (co wpisuje się w zasygnalizowaną wyżej specyfikę współczesnych realiów społeczno-kulturowych).

Założyciele strony deklarują, że niepokojące jest dla nich traktowanie rozwodów i rozstań jako najprostszego i najbardziej efektywnego sposobu rozwią- 
zywania problemów między partnerami. By propagować inne modele przezwyciężania kryzysów małżeńskich i partnerskich, stworzyli Fundację „Rozwód? Poczekaj!", której działalność w znacznej mierze realizowana jest w przestrzeni internetu. Jej celem jest propagowanie innych niż rozwód i rozstanie sposobów rozwiązywania kryzysów małżeńskich. Nadrzędnie traktowana jest tu profilaktyka, a zakończenie związku stanowi dopuszczalne, lecz ostateczne rozwiązanie nawarstwiających się problemów.

Osoby odwiedzające stronę www.rozwodpoczekaj.org.pl mogą zapoznać się ze zróżnicowaną ofertą zajęć skierowanych zarówno do osób, które dopiero planują wejście w związek małżeński, jak i do tych, których staż małżeński jest już znaczący. Propagowane przez twórców strony wzory kulturowe ukierunkowane są na zachowanie stabilności związków małżeńskich (lub partnerskich). U podstaw tej inicjatywy leży założenie, że rodzina (pojmowana nie tylko w sposób tradycyjny) stanowi naturalne i najkorzystniejsze środowisko egzystencji i rozwoju jednostki. Podobnych przedsięwzięć jest zresztą więcej (np. www.rozwod przemyslto.pl, malzenstwojestdobre.pl, www.mamaitata.org.pl itp.).

Wszystkie one koncentrują się na propagowaniu pojmowania rodziny jako fundamentu egzystencji w wymiarze aksjologicznym. Ich działanie zogniskowane jest na wskazywaniu możliwości rozwiązywania problemów małżeńsko-rodzinnych, które pojawią się na różnych etapach rozwoju struktur rodzinnych. W ten sposób stanowią swoistą przeciwwagę dla portali promujących ideę indywidualizmu, których działalność w zasadniczej mierze polega na „uelastycznianiu” związków, rozumianym jako promowanie rozwiązań ułatwiających wychodzenie z problematycznych układów rodzinnych i nawiązywanie nowych.

Zasygnalizowane powyżej przykłady wskazują na zróżnicowane oddziaływanie globalnej sieci w zakresie utrwalania i dekonstrukcji związków małżeńskich. Z jednej strony szereg istniejących stron internetowych skłania do podjęcia decyzji o rozstaniu i ułatwia przeprowadzenie procedury rozwodowej, z drugiej zaś można przywołać szereg przykładów wskazujących na utrwalające i wspierające małżeństwo oddziaływanie treści obecnych w sieci.

\section{Internet a komunikacja wewnattrzrodzinna}

W badaniach nad zachowaniami w sieci sporo miejsca poświęca się zagadnieniu komunikacji zapośredniczonej komputerowo (CMC - computer-mediated communication). Podkreśla się przy tym, że komunikowanie via internet jest szybkie, łatwe i efektywne. Kiedy jednak analizuje się zastosowanie tej funkcji sieci w odniesieniu do rodziny, okazuje się, że jej wykorzystanie w jednakowym stopniu może scalać, jak i dezintegrować tę strukturę społeczną. 
Powszechny dostęp do internetu niewątpliwie ułatwia kontakty pomiędzy członkami rodziny w sytuacjach przestrzennego oddalenia. Internet niejednokrotnie staje się narzędziem podtrzymującym więzi rodzinne, dostarczając możliwości komunikowania się dzieci i rodziców, gdy mieszkają oni daleko od siebie. Jak zauważa Anna Bąk, w takich wypadkach internet nie tylko nie zaciera granic rodzinnych, ale przeciwnie, przyczynia się do utrzymywania i ułatwiania przekazu między rodzicami i dziećmi, np. poprzez wiadomości oraz wymianę zdjęć i informacji ${ }^{33}$. Internet staje się w ten sposób środkiem komunikacji, który korzysta z już istniejących relacji, które są uwydatniane w zależności od siły więzi lub zaangażowania komunikujących się jednostek. Możliwość wykorzystania internetowych kanałów informacji, takich jak poczta elektroniczna czy komunikatory internetowe sprawia, że kontakty pomiędzy członkami rodziny stają się częstsze i bardziej intensywne niż w czasach, gdy kontakt był możliwy wyłącznie za pośrednictwem poczty tradycyjnej czy telefonu. Komunikacja za pośrednictwem internetu okazuje się wygodna - nawiązanie kontaktu nie wymaga bowiem szczególnego wysiłku, związanego chociażby z koniecznością wyjścia z domu, a także tańsza w stosunku do - przykładowo - rozmów telefonicznych.

Te atuty sieci są wykorzystywane między innymi przez rodziny, których członkowie zostali rozdzieleni wskutek emigracji. W takich okolicznościach utrzymanie regularnego kontaktu wydaje się być warunkiem przetrwania struktury rodzinnej. Wyniki analiz przeprowadzonych przez Annę Bąk ${ }^{34}$ wskazują na znaczący spadek częstotliwości kontaktów młodych emigrantów z rodzicami, który nastąpił po ich wyjeździe z kraju. Dla zdecydowanej większości badanych internet stanowi ważny środek komunikacji z najbliższymi. Mimo zmniejszenia ilości kontaktów z rodziną respondenci raczej nie deklarowali pogorszenia się tych kontaktów - w ocenie większości z nich kontakty te nie uległy zmianie, natomiast niektórzy wskazywali na nieznaczne ich polepszenie. Emigranci podkreślali, że atutem komunikacji za pośrednictwem internetu są relatywnie niskie koszty użytkowania sieci. Twierdzili także, że podczas prowadzonych w ten sposób rozmów z rodziną poruszają praktycznie wszystkie tematy. Preferują przy tym formy komunikacji synchronicznej (tj. telefon, komunikatory głosowe i tekstowe). Do asynchronicznych form komunikacji najczęściej wskazywanych przez emigrantów należy poczta elektroniczna i portale społecznościowe. Podkreślić jednak należy, że mimo że internet jest ważnym środkiem komunikacji polskich emigrantów z ich rodzinami w kraju, to jednak najbardziej preferowaną formą kontaktu pozostaje ten rze-

33 A. Bąk, Komunikacja polskich emigrantów z rodziną za pośrednictwem internetu, [w:] Całe życie..., dz. cyt., s. 211.

34 Tamże, s. 213-228. 
czywisty, face to face. Można na tej podstawie wnioskować, że internet nie zastępuje kontaktów bezpośrednich z rodziną, może jednak znacząco pomagać w podtrzymaniu więzi między jej członkami.

Warto również wspomnieć o tym, że sieć stwarza możliwość integracji szerszych struktur rodzinnych. Popularność serwisów społecznościowych, takich jak Facebook.com, czy cieszącego się do niedawna dużą popularnością portalu NaszaKlasa.pl przyczyniły się do odnowienia wielu znajomości sprzed lat. Użytkownicy tego typu serwisów zyskali możliwość odszukania osób, które znali w przeszłości, i nawiązania z nimi ponownego kontaktu. Niektórzy z nich w ten sposób starają się odnaleźć członków dalszej rodziny, z którymi dawno utracili kontakt. Zdarza się, że starają się odbudować te relacje „w realu” - internet służy im więc na ogół jedynie do nawiązania kontaktu, a kontynuowanie znajomości i budowanie rodzinnych więzi odbywa się już w przestrzeni offline. Ponownie więc okazuje się, że sieć może wspierać rodzinę, ale raczej nie stanowi substytutu przestrzeni, w której mają miejsce interakcje o charakterze bezpośrednim.

Wśród badaczy internetu nie brakuje jednak również takich, którzy zwracają uwagę na fakt, że nadmierne korzystanie z tego medium powoduje atomizację rodziny. Kiedy bowiem aktywność jej członków orientuje się na przestrzeń wirtualną, może dojść do rozluźnienia więzi między nimi. Powtarzające się sytuacje, kiedy rodzice i dzieci przedkładają aktywność w sieci nad wspólne spędzanie wolnego czasu w rodzinnym gronie, mogą pociągać za sobą szereg konsekwencji dla życia rodzinnego. Oddalanie się od siebie, brak wspólnych zainteresowań, konflikty międzypokoleniowe, problemy wychowawcze - to tylko niektóre z możliwych skutków zorientowania aktywności indywidualnej członków rodziny na przestrzeń wirtualną.

Pedagodzy zwracają uwagę głównie na problemy związane z wykorzystywaniem sieci przez dzieci i młodzież ${ }^{35}$. Internet jest bowiem szczególnie atrakcyjny dla młodszych pokoleń, które chętnie spędzają w przestrzeni wirtualnej większą część swojego wolnego czasu. Izolacja od świata realnego, spowodowana przeniesieniem aktywności do przestrzeni wirtualnej, może skutkować pogorszeniem się relacji z rodzicami. Badacze zwracają uwagę na fakt, że internet wzmacnia zachowania agresywne. Dzieci nie tylko stykają się w sieci z obrazami przemocy, ale także mogą wejść w kontakt z osobami, które stosują agresję i przemoc ${ }^{36}$. Ponieważ jednocześnie łatwo ulegają wpływom, dosyć szybko

35 Wśród prac pedagogów zainteresowanych tym zagadnieniem wymienić można m.in. M. Więczkowska, Internet $w$ zyciu rodzinnym - szanse i zagrożenia, „Edukacja Zdrowotna. Kwartalnik Naukowy WSEZ” vol. 4 (2007) nr 2; M. Puchała, Komunikatory internetowe zagrożeniem dla dzieci, [w:] Cyberświat. Możliwości i zagrożenia, red. J. Bednarek, A. Andrzejewska, Warszawa 2009.

36 R. Hughes, Jr., J. D. Hans, Understanding..., dz. cyt., s. 510. 
zaczynają powielać wzorce, z którymi mają styczność, co powoduje konflikty $\mathrm{z}$ najbliższym otoczeniem, a więc przede wszystkim $\mathrm{z}$ rodziną.

Ponadto nadmierne korzystanie z sieci może prowadzić do uzależnienia. Jak zauważa Małgorzata Więczkowska, najczęściej dotyczy ono komunikacji synchronicznej (rozmowy, gry) ${ }^{37}$. Mimo że brak jest miarodajnych danych dotyczących skali tego problemu, to biorąc pod uwagę coraz szersze możliwości, jakie stwarza internet, można przypuszczać, że dotyka on wielu młodych ludzi. Przeżywający problemy związane z okresem dorastania młodzi ludzie poszukują zrozumienia w społecznościach internautów, bowiem często dorośli nie wykazują się wystarczająco dużym zrozumieniem dla ich sytuacji. W przestrzeni internetu uzyskują pozytywne wzmocnienia, mogą oderwać się od rzeczywistości, w której ograniczeni są zakazami formułowanymi przez dorosłych.

Uzależnienie od internetu rozwija się tak samo jak inne formy uzależnienia i ma tak samo negatywne konsekwencje dla jednostki, jak i dla jej rodziny. Obok szkód psychicznych czy nawet fizycznych, które bezpośrednio wpływają na uzależnionego, siecioholizm wywiera wpływ na funkcjonowanie całej rodziny. Uzależnienie jest zawsze swoistym sprawdzianem jakości więzi w rodzinie - od tego, jak jest ona silna, zależy, czy uda się jej członkom problem ten przezwyciężyć. Warto przy tym zauważyć, że uzależnienia bywają de facto symptomem problemów w rodzinie - niejednokrotnie członkowie rodziny popadają $\mathrm{w}$ nałogi, ponieważ nie potrafią sobie poradzić z rodzinnymi nieporozumieniami i konfliktami oraz niezrozumieniem przez najbliższych. Podobnie jak to ma miejsce w przypadku innych uzależnień, tak i siecioholizm powoduje współuzależnienie. Internetoholizm dotyka więc nie tylko jednostkę, ale także wszystkie osoby, którym na niej zależy. Skutkuje to - między innymi - brakiem umiejętności niesienia uzależnionemu skutecznej pomocy.

Symbolem uzależnionego nastolatka jest osoba odizolowana od świata zewnętrznego, zamknięta w swoim pokoju, która do życia zdaje się potrzebować jedynie komputera $\mathrm{z}$ dostępem do internetu. Syndrom ten zdiagnozowano po raz pierwszy i opisano w Japonii, gdzie nazwano go „hikikomori”38. Problem ten dotyka coraz więcej młodych ludzi, którzy odcinają się od najbliższych, aby móc skoncentrować się na świecie wirtualnym, który jawi się im jako rzeczywistość daleko bardziej atrakcyjna niż świat realny.

Oczywiście nie tylko dzieci czy młodzież narażone są na ryzyko uzależnienia od internetu - także osoby dorosłe, borykające się z rozmaitymi problemami bywają podatne na oddziaływanie sieci. Mowa tu m.in. o gospodyniach do-

\footnotetext{
37 M. Więczkowska, Internet..., dz. cyt., s. 7.

38 http://www.uzaleznieniabehawioralne.pl/index.php?option=com_content\&view $=$ article\&id=273\&Itemid=219 (31.03.2015).
} 
mowych, które ze względu na ograniczone kontakty społeczne i relatywnie dużą ilość wolnego czasu orientują swoją aktywność na kontakty wirtualne. Problem dorosłych internetoholików jest z punktu widzenia relacji w rodzinie równie ważny jak problem dzieci. Niemniej jednak to w najmłodszym pokoleniu uzależnienie od internetu ujawnia się szczególnie mocno, stąd też uwaga badaczy jest skierowana przede wszystkim na te osoby.

\section{Internet, praca a rodzina}

Jednym z podstawowych warunków prawidłowego funkcjonowania rodziny jest jej stabilność ekonomiczna. Stosunki wewnątrzrodzinne w dużej mierze zależą bowiem od stopnia zaspokojenia podstawowych potrzeb członków tej mikrostruktury społecznej. Deprywacja potrzeb podstawowych wywołuje często konflikty i nieporozumienia, które mogą prowadzić do rozpadu więzi. Dlatego też tak ważne jest, aby rodzice posiadali stałe zatrudnienie, ponieważ pozwala ono rodzinie egzystować bez zakłóceń. Również w tym obszarze internet może wspomagać rodzinę. Jednak zauważyć trzeba, że zdarzają się sytuacje, kiedy praca wspomagana przez możliwości sieciowe negatywnie oddziałuje na relacje rodzinne.

Powszechny dostęp do internetu zrewolucjonizował rynek pracy. Trudno dziś wyobrazić sobie funkcjonowanie przedsiębiorstw bez dostępu do globalnej sieci, która - między innymi - umożliwia przedstawicielom wielu profesji świadczyć pracę w sposób zdalny, bez konieczności przemieszczania się do siedzib firm, które ich zatrudniają. Telepraca, czyli wykonywanie obowiązków wynikających z zatrudnienia za pomocą środków masowego przekazu, wydaje się dogodnym rozwiązaniem zwłaszcza dla rodzin wychowujących najmłodsze dzieci. Takie rozwiązanie pozwala zaoszczędzić czas, a także dostosować godziny pracy do obowiązków związanych z opieką nad dziećmi, możliwe staje się zatem pogodzenie obowiązków zawodowych z rodzicielskimi. Nie ma więc potrzeby, aby zatrudniać osobę do opieki nad dzieckiem, a stała obecność rodzica w domu wpływa integrująco na środowisko rodzinne.

Z możliwości telepracy korzystają głównie kobiety, które - nie chcąc tracić kontaktu z dzieckiem w pierwszym etapie jego życia - decydują się w ten sposób pogodzić rolę pracownicy i rolę matki. Wydaje się, że możliwość świadczenia pracy online jest dobrym sposobem na uniknięcie konfliktu wspomnianych ról, jednak warto mieć na uwadze, że nie każdy rodzaj pracy da się świadczyć zdalnie.

Stały dostęp pracownika do sieci bywa jednak równie często przyczyną osłabienia więzi rodzinnych. Wyposażeni w służbowe telefony czy laptopy pracownicy „przynoszą” pracę do domu. W ten sposób granica pomiędzy życiem rodzin- 
nym i obowiązkami służbowymi zaciera się, ponieważ niezależnie od pory dnia i miejsca wciąż są w pracy. W rezultacie czas, który powinni spędzić z rodziną, jest przeznaczany na załatwianie spraw służbowych, a ich obecność w domu ma wymiar wyłącznie fizyczny - w rzeczywistości są wciąż zaabsorbowani czynnościami związanymi z pracą zawodową. Takie sytuacje prowadzą do nieporozumień, a nawet konfliktów, będących przyczyną zaniedbywania obowiązków rodzinnych. W rezultacie osłabieniu ulegają więzi rodzinne, a zapracowany domownik zostaje odsunięty od spraw, które dla jego rodziny są ważne.

\section{Podsumowanie}

Za pośrednictwem internetu komunikujemy się z innymi, nawiązując lub podtrzymując kontakty towarzyskie, załatwiając sprawy służbowe czy urzędowe; dzięki niemu w łatwy sposób uzyskujemy informacje, mamy dostęp do rozmaitych usług (bankowość elektroniczna, zakupy online itp.); sieć jest też przestrzenią rozrywki, która umożliwia m.in. granie w gry online, oglądanie filmów, słuchanie muzyki itp. W oczywisty sposób zatem globalna sieć kształtuje także relacje rodzinne.

Przedstawione powyżej refleksje dotyczą jedynie wybranych aspektów tego wpływu - sygnalizowane oddziaływania mają bowiem wymiar o wiele szerszy. Nie ma jednak wątpliwości, że powszechny dostęp do internetu ma niejednoznaczny charakter. Jak staraliśmy się dowieść, może on przyczyniać się zarówno do rozpadu, jak i integracji związków małżeńskich. Dzięki dostępowi do sieci powstają zalążki nowych rodzin, ale też za jego sprawą rozpadają się już istniejące struktury. Jest ona niebywałym ułatwieniem w zakresie komunikacji i integracji (w szczególności dla rodzin rozdzielonych w wyniku emigracji zarobkowej), lecz bywa także czynnikiem atomizacji i alienacji poszczególnych członków. Internet ułatwia współcześnie znalezienie i wykonywanie pracy (co przekłada się na lepszą sytuację ekonomiczną rodzin), ale również przyczynia się do nadmiernego zaabsorbowania obowiązkami zawodowymi i zaniedbywania obowiązków rodzinnych.

Analizując sytuację współczesnych rodzin, można zatem dojść do wniosku, że wbrew temu, co potocznie się sądzi, sieć nie tylko nie musi przyczyniać się do osłabienia więzi między ludźmi (również tych najbliższych i najbardziej intymnych), ale wręcz może je wzmacniać. Wydaje się, że internet stanowi po prostu narzędzie, które - tak jak każde inne - można wykorzystać dla poprawy życia bądź do wyrządzenia komuś krzywdy. Kluczowe wydaje się w tym kontekście dbanie na poziomie makrostrukturalnym o budowanie odpowiednich kompetencji społeczno-kulturowych, pozwalających na 
wykorzystanie możliwości stwarzanych przez zaawansowaną technologię dla trwania i rozwoju rodzin.

\section{Bibliografia}

Barani K., Wirtualne wspólnoty kobiet na forach internetowych jako źródło wsparcia w przygotowaniu do macierzyństwa, [w:] Całe życie w Sieci, red. B. Szmigielska, Kraków 2008.

Bargh J. A., McKenna K. Y. A., The Internet and Social Life, „Annual Review of Psychology” (2004) nr 55.

Bąk A., Komunikacja polskich emigrantów z rodzina za pośrednictwem internetu, [w:] Całe życie w Sieci, red. B. Szmigielska, Kraków 2008.

Castells M., Galaktyka Internetu, przeł. T. Hornowski, Poznań 2003.

Dyczewski L., Rodzina polska i kierunki jej przemian, Warszawa 1981.

Gergen K. J., Nasycone Ja. Dylematy tożsamości w życiu wspótczesnym, przeł. M. Marody, Warszawa 2009.

Haythornthwaite C., Wellman B., The Internet in Everyday Life: An Introduction, [w:] The Internet in Everyday Life, red. B. Wellman, C. Haythornthwaite, Oxford 2002.

Hughes R., Jr., Hans J. D., Understanding the Effects of the Internet on Family Life, [w:] Handbook of contemporary families, red. M. Coleman, L. Ganong, Thousand Oaks, C.A 2004.

Jankowiak B., Nieformalne zwiazki jedno- $i$ dwuptciowe jako alternatywne formy życia małżeńsko-rodzinnego. Analiza jakości i stabilności relacji, „Studia Edukacyjne” 26 (2013).

Popenoe D., American Family Decline, 1960-1990: A Review and Appraisal, „Journal of Marriage and Family" vol. 55 (1993) nr 3.

Pospiszyl I., Źródła trwałości rodziny we wspótczesnym społeczeństwie, „Problemy Rodziny” (1998) $\mathrm{nr} 2$.

Przybylska A., Korzystanie z mediów, [w:] Współczesne społeczeństwo polskie, red. A. Giza, M. Sikorska, Warszawa 2012.

Puchała M., Komunikatory internetowe zagrożeniem dla dzieci, [w:] Cyberświat. Możliwości i zagrożenia, red. J. Bednarek, A. Andrzejewska, Warszawa 2009.

Rocznik Demograficzny GUS, Warszawa 2013.

Szczepański J., Elementarne pojęcia socjologii, Warszawa 1972.

Tyszka Z., Rodzina współczesna - jej geneza i kierunki przemian, [w:] Rodzina wspótczesna, red. M. Ziemska, Warszawa 1999.

Tyszka Z., System metodologiczny poznańskiej szkoły socjologicznych badań nad rodzina, Poznań 1997.

Dijk J., van, Społeczne aspekty nowych mediów, przeł. J. Konieczny, Warszawa 2010.

Wallace P., Psychologia Internetu, przeł. T. Hornowski, Poznań 2003.

Wellman B., Hogan B., Internet w życiu codziennym, przeł. M. Filiciak, „Kultura Popularna” $12(2005) \mathrm{nr} 2$. 
Więczkowska M., Internet w życiu rodzinnym - szanse i zagrożenia, „Edukacja Zdrowotna. Kwartalnik Naukowy WSEZ" vol. 4 (2007) nr 2.

\section{Netografia}

http://interaktywnie.com/badania-i-megapanel/oto-najpopularniejsze-serwisy-randkowew-europie-250222 (30.05.2015).

http://www.rozwod.pl/ (26.05.2015).

http://www.uzaleznieniabehawioralne.pl/index.php?option=com_content\&view=article\& $\mathrm{id}=273$ \&Itemid=219 (31.03.2015).

http://www.wirtualnemedia.pl/artykul/top-10-serwisow-randkowych-sympatia-wyprzedzilaedarling-w-gore-sympatiaplus\# (30.05.2015).

Społeczeństwo informacyjne w Polsce w roku 2014, www.stat.gov.pl (29.05.2015). 